\title{
In vitro bioassays to assess drinking water quality
}

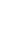

(1)

\author{
Peta A. Neale ${ }^{\mathrm{a}}$ and Beate I. Escher ${ }^{\mathrm{b}, \mathrm{c}^{*}}$
}

${ }^{a}$ Australian Rivers Institute, School of Environment and Science, Griffith University, Southport QLD 4222, Australia

${ }^{\mathrm{b}}$ UFZ - Helmholtz Centre for Environmental Research, 04318 Leipzig, Germany

${ }^{c}$ Eberhard Karls University Tübingen, Environmental Toxicology, Center for Applied Geoscience, 72074 Tübingen, Germany

*Corresponding author: beate.escher@ufz.de; +49 3412351244

\section{Current Opinion in Environmental Science \& Health} https://doi.org/10.1016/j.coesh.2018.06.006

C2018. This manuscript version is made available under the CC-BY-NC-ND 4.0 license http://creativecommons.org/licenses/by-nc-nd/4.0/ 
Abstract: In vitro assays indicative of different stages of cellular toxicity pathways have been applied to both source water and drinking water. The majority of studies showed a decrease in receptor-mediated effects after drinking water treatment due to the removal of micropollutants, while reactive toxicity typically increased after chlorination due to the formation of disinfection byproducts. Using both chemical analysis and bioanalysis, iceberg modelling can be applied to determine which chemicals are contributing to the observed effect, though one limitation is that typical sample pretreatment for bioanalysis fails to capture volatile chemicals. Bioassays are increasingly sensitive and effects can be detected in clean samples, thus effect-based trigger values can be applied to determine whether an effect in drinking water is acceptable.

Keywords: bioanalysis; drinking water treatment; effect-based trigger value; estrogenic activity; iceberg modelling; reactive toxicity 


\section{Introduction}

There is increasing concern about the presence of micropollutants, such as pharmaceuticals, pesticides and industrial compounds, in drinking water, with micropollutants detected in both source water and treated drinking water around the world [1-4]. During water treatment, disinfection by-product (DBPs) can form from the reaction of disinfectants, such as chlorine, chloramine and ozone, with organic and inorganic matter naturally present in source water [5], with DBPs commonly detected in disinfected drinking water [6,7]. Further, micropollutant transformation products (TP) can also form during water treatment with disinfectants and during other advanced oxidation processes [8]. Consequently, drinking water can contain a complex mixture of micropollutants, TPs and DBPs (Figure 1). While targeted chemical analysis is often used for monitoring drinking water quality, it is unlikely to comprehensively capture the diversity of chemicals potentially present in drinking water, especially as many micropollutants and their TPs will be present at low nanogram per litre concentrations. Instead, in vitro bioassays can be applied complementary to chemical analysis as they can incorporate the mixture effects of all active chemicals in a sample without the identification of single compounds $[9,10]$. They are also riskscaled, meaning that more potent chemicals will have a greater contribution to the mixture effect than less potent chemicals at similar concentrations. In the current study we review the application of high-throughput in vitro assays to drinking water, with a focus on studies that have been published in the last two years. In addition, we also discuss the application of iceberg modelling for drinking water, sample preparation considerations and the need for effect-based trigger values.

\section{Application of in vitro bioassays to drinking water}

In vitro bioassays indicative of different stages of cellular toxicity pathways, including induction of xenobiotic metabolism $[11,12]$, hormone receptor-mediated effects $[1,13,14]$, reactive modes of action $[15,16]$, adaptive stress responses $[11,17,18]$ and cytotoxicity $[19,20]$, have been applied to evaluate effects in drinking water. While some of the assays utilized in the cited studies are not currently high-throughput (e.g. run in 96 or 384 well plate), they all have the potential to be highthroughput (e.g. Ames plate-incorporation test using agar plates versus the Ames fluctuation test in 384 well plates).

The effect in a bioassay is often expressed as a bioanalytical equivalent concentration (BEQ $\left.{ }_{\text {bio }}\right)$, which relates the effect of a sample to the concentration of a reference compound that would elicit the same response as the mixture of chemicals in the tested water sample. For example, estrogenic activity is often expressed as an estradiol equivalent concentration (EEQ). 
Estrogenic activity has been widely studied in treated drinking water using a range of in vitro assays [11-14, 21-25], with an overview of reported activity provided in Figure 2. Many studies also measure estrogenic activity in source water and compare $\mathrm{BEQ}_{\text {bio }}$ before and after treatment, with 39 to $99 \%$ removal of estrogenic activity reported [12, 13, 23-25], which indicates the removal or degradation of causative compounds. In many cases, estrogenic activity was below the assay detection limit after treatment. While less studied, other types of hormonal activity, such as activation of the androgen receptor (AR), progesterone receptor (PR), glucocorticoid receptor (GR) and thyroid receptor (TR), have not been detected in drinking water [1, 11, 12, 26-28], with the exception of low androgenic activity in one drinking water sample from the Netherlands [29].

Reactive toxicity, specifically genotoxicity $[16,18,19]$ and mutagenicity $[15,25,30]$, is also commonly studied in drinking water. The majority of studies typically showed an increase in reactive toxicity after water treatment with disinfectants $[15,16,18,25,30]$, which is attributed to the formation of DBPs. In contrast, while some source water samples induced a response in the micronucleus test for genotoxicity and the Ames fluctuation test for mutagenicity, Shi et al. [12] found that none of the corresponding treated water samples had an effect after conventional treatment (coagulation, sedimentation and sand filtration) with chlorination. The effect in the source water was attributed to the presence of micropollutants, such as polycyclic aromatic hydrocarbons and polychlorinated biphenyls, as mutagenicity in the source water was only observed after metabolic activation using rat liver S9.

While most studies focus on surface water as a source of drinking water, several studies have applied in vitro assays to assess reactive toxicity of drinking water from groundwater sources [20, 30, 31]. In all studies, there was negligible toxicity in treated water, with Pellacani et al. [20] observing a decrease in genotoxicity and cytotoxicity after treatment despite disinfection being the only form of treatment. The negligible toxicity after treatment was attributed to the low concentrations of DBP precursor natural organic matter in groundwater.

As all active chemicals will induce a response in a bioassay, it is difficult to distinguish between the effect of micropollutants, TPs and DBPs in the assay. In an attempt to differentiate the contribution of micropollutants and DBPs to the oxidative stress response in samples from drinking water distribution systems, Hebert et al. [17] compared $\mathrm{BEQ}_{\text {bio }}$ before and after treatment (Equation 1) and found that DBPs could contribute up to $58 \%$ of the oxidative stress response. A limitation of this approach is that it does not account for removal of micropollutants during treatment and thus may potentially underestimate the contribution from DBPs. 


$$
\mathrm{BEQ}_{\mathrm{bio}, \mathrm{DBP}}=\mathrm{BEQ}_{\mathrm{bio}, \text { after treament }}-\mathrm{BEQ}_{\mathrm{bio}, \text { before treatment }}
$$

\section{Which chemicals are driving the observed effects in drinking water?}

Several studies have applied both bioanalysis and chemical analysis to assess drinking water quality $[12,17,30]$ and iceberg modelling can be used to determine the contribution of detected chemicals to the observed effect [32]. In iceberg modelling $\mathrm{BEQ}_{\text {bio }}$ is compared to bioanalytical equivalent concentrations from chemical analysis $\left(\mathrm{BEQ}_{\mathrm{chem}}\right)$, which is calculated using the detected chemical concentration and the relative effect potency $\left(\mathrm{REP}_{\mathrm{i}}\right)$ of the detected chemical to the assay reference compound (Figure 3). Comparison of $\mathrm{BEQ}_{\text {bio }}$ and $\mathrm{BEQ}_{\mathrm{chem}}$ can reveal if a certain chemical or group of chemicals can explain the majority of the effect or whether the effect is predominately triggered by unknown chemicals. Iceberg modelling has been applied to both source water and treated drinking water recently, with natural and synthetic hormones found to explain the majority of observed estrogenic activity $[12,13,23]$. In contrast, the detected chemicals could only explain between 0.2 to $6.5 \%$ of the dioxide-like response in the EROD assay in source water [12]. This is in line with previous observation in surface water [33]. A similar approach is the TIC-Tox metric, which aims to determine the forcing agents in disinfected water [34]. Using semi-quantitative total ion current (TIC) data from Jeong et al. [19] and cytotoxicity data (Tox) from Wagner and Plewa [35], haloacetonitriles and haloacetamides were found to be the main drivers of toxicity in drinking water extracts [34].

The effect of the individual detected chemicals is required for iceberg modelling in order to

130 calculate $\mathrm{REP}_{\mathrm{i}}$. Recently, the effect of conventional and emerging DBPs have been fingerprinted in 131 bioassays commonly used for water quality monitoring [e.g. 6, 35-39]. While technically in vivo, 132 early life-stage whole organism assays, such as the fish embryo toxicity (FET) assay, can also be 133 run in high-throughput mode and are considered legally as in vitro, with a recent study 134 fingerprinting the effects of individual DBPs in the FET assay [40]. In addition, the US EPA 135 ToxCast database (https://actor.epa.gov/dashboard/) contains effect data for over 9000 chemicals, 136 including many DBPs and other micropollutants detected in drinking water. It has already been 137 utilized for iceberg modelling in surface water and wastewater [33, 41].

\section{Sample pretreatment for bioanalysis}

140 As micropollutants are typically present in drinking water at low concentrations, sample enrichment 141 is required prior to applying in vitro bioassays, with several studies enriching drinking water 
samples 10,000 times or more $[12,19,31,42]$. The majority of studies apply solid phase extraction (SPE) [e.g. 12, 13, 14] or XAD resins [e.g. 15, 19, 31] to enrich drinking water. While these extraction methods will extract non-volatile and semi-volatile chemicals, they are unable to capture volatile chemicals. This is particularly pertinent for DBPs, as many are volatile and thus typical enrichment techniques may not capture all of the toxicologically relevant chemicals. To investigate this further, Stalter et al. [43] applied both SPE and purge and cold-trap methods to capture both non-volatile and volatile DBPs from disinfected drinking water samples. For the bacterial Microtox assay the volatile fraction induced a greater effect than the non-volatile fraction in some samples, while the non-volatile fraction induced the majority of the oxidative stress response in the AREc32 assay. Similarly, using iceberg modelling, Hebert et al. [17] found that volatile DBPs only had a minor contribution to the observed oxidative stress response in samples collected from French drinking water distribution systems. As these examples only focus on two assays, further work is required to understand the contribution of volatile and non-volatile DBPs in other assays commonly applied to water extracts, such as the Chinese hamster ovary (CHO) cell line [19] and the Ames assay $[15,25]$.

\section{Is drinking water quality acceptable?}

Many in vitro assays, particularly reporter gene assays, are very sensitive and can detect an effect in clean water samples with sufficient enrichment, including highly treated drinking water and bottled water [17]. However, just because a water sample induces a response in a bioassay does not mean that the water quality is necessarily unacceptable. Consequently, effect-based trigger values (EBT) can be applied to differentiate between acceptable and unacceptable water quality [44], with drinking water EBTs developed for a number of in vitro assays [29, 45, 46]. Estrogenic activity in drinking water was compared to available EBTs for the ER-CALUX, E-Screen and yeast estrogen screen (YES) assays (Figure 2). In the majority of cases, the reported activity was far below the corresponding EBT, with the exception of two treated drinking water samples from China [12]. Further, the oxidative stress response in drinking water from France and Australia was compared to the proposed oxidative stress EBT from Escher et al. [46] (Figure 4). While there was a margin of safety of 2 to 16 for treated drinking water from France [17], drinking water sampled in Australia often exceeded the EBT [18, 26, 47]. EBTs are important tools for interpreting bioassay results, though further work is required to derive EBTs for more assays used for drinking water quality monitoring. 


\section{Conclusions}

In vitro bioassays are a valuable tool to complement to chemical analysis for drinking water quality monitoring as they are able to integrate the effects from a complex mixture of micropollutants, TPs and DBPs. While a range of effects, including estrogenic activity, oxidative stress response, reactive toxicity and cytotoxicity, have been detected in treated drinking water, the effects are generally low and are mostly below available EBTs. Although volatile DBPs are not captured by common sample pretreatment processes, iceberg modelling has suggested that volatile DBPs only have a minor contribution to the oxidative stress response, though this remains to be seen for other biological endpoints. To better understand the contribution of micropollutants and DBPs to the observed effect in drinking water a bioassay test battery covering different stages of cellular toxicity pathways is recommended. Based on the current review, a suitable test battery for drinking water may include assays indicative of activation of the estrogen receptor, genotoxicity, oxidative stress response and cytotoxicity.

\section{Acknowledgments}

This research did not receive any specific grant from funding agencies in the public, commercial, or not-for-profit sectors.

\section{References}

Papers of particular interest, published since 2015, have been highlighted as:

* of special interest

1. Leusch FDL, Neale PA, Arnal C, Aneck-Hahn NH, Balaguer P, Bruchet A, Escher BI, Esperanza M, Grimaldi M, Leroy G, Scheurer M, Schlichting R, Schriks M, Hebert A: Analysis of endocrine activity in drinking water, surface water and treated wastewater from six countries, Water Res. 2018, 139:10-18. *Worldwide comparison of chemical concentrations and hormonal activity in drinking water and comparison with other water types, including surface water and treated wastewater.

2. Tröger R, Klöckner P, Ahrens L, Wiberg K: Micropollutants in drinking water from source to tap - Method development and application of a multiresidue screening method, Sci. Total Environ. 2018, 627:1404-1432.

3. Glassmeyer ST, Furlong ET, Kolpin DW, Batt AL, Benson R, Boone JS, Conerly O, Donohue MJ, King DN, Kostich MS, Mash HE, Pfaller SL, Schenck KM, Simmons JE, Varughese EA, Vesper SJ, Villegas EN, Wilson VS: Nationwide reconnaissance of contaminants of emerging concern in source and treated drinking waters of the United States, Sci. Total Environ. 2017, 581:909-922. 
4. Machado KC, Grassi MT, Vidal C, Pescara IC, Jardim WF, Fernandes AN, Sodre FF, Almeida FV, Santana JS, Canela MC, Nunes CRO, Bichinho KM, Severo FJR: A preliminary nationwide survey of the presence of emerging contaminants in drinking and source waters in Brazil, Sci. Total Environ. 2016, 572:138-146.

5. Richardson SD, Postigo C: Formation of DBPs: State of the Science. In Recent Advances in Disinfection by-Products. Edited by Karanfil T, Mitch B, Westerhoff P, Xie Y. American Chemical Society; 2015:189-214.

6. Jeong CH, Postigo C, Richardson SD, Simmons JE, Kimura SY, Marinas BJ, Barcelo D, Liang P, Wagner ED, Plewa MJ: Occurrence and comparative toxicity of haloacetaldehyde disinfection byproducts in drinking water, Environ. Sci. Technol. 2015, 49:13749-13759.

7. Krasner SW, Kostopoulou M, Toledano MB, Wright J, Patelarou E, Kogevinas M, Villanueva CM, Carrasco-Turigas G, Marina LS, Fernandez-Somoano A, Ballester F, Tardon A, Kargaki S, Nieuwenhuijsen MJ: Occurrence of DBPs in drinking water of European regions for epidemiology studies, J. Am. Water Works Assoc. 2016, 108:E501-E512.

8. Postigo C, Richardson SD: Transformation of pharmaceuticals during oxidation/disinfection processes in drinking water treatment, J. Hazard. Mater. 2014, 279:461-475.

9. Escher BI, Leusch FDL: Bioanalytical tools in water quality assessment. IWA Publishing; 2012. 10. Wernersson A-S, Carere M, Maggi C, Tusil P, Soldan P, James A, Sanchez W, Dulio V, Broeg K, Reifferscheid G, Buchinger S, Maas H, Van Der Grinten E, O’Toole S, Ausili A, Manfra L, Marziali L, Polesello S, Lacchetti I, Mancini L, Lilja K, Linderoth M, Lundeberg T, Fjällborg B, Porsbring T, Larsson DJ, Bengtsson-Palme J, Förlin L, Kienle C, Kunz P, Vermeirssen E, Werner I, Robinson CD, Lyons B, Katsiadaki I, Whalley C, den Haan K, Messiaen M, Clayton H, Lettieri T, Carvalho RN, Gawlik BM, Hollert H, Di Paolo C, Brack W, Kammann U, Kase R: The European technical report on aquatic effect-based monitoring tools under the water framework directive, Environ. Sci. Eur. 2015, 27:1-11.

11. Rosenmai AK, Lundqvist J, le Godec T, Ohlsson Å, Tröger R, Hellman B, Oskarsson A: In vitro bioanalysis of drinking water from source to tap, Water Res. 2018, 139:272-280.

12. Shi P, Zhou SC, Xiao HX, Qiu JF, Li AM, Zhou Q, Pan Y, Hollert H: Toxicological and chemical insights into representative source and drinking water in eastern China, Environ. Pollut. 2018, 233:35-44. *This study applied chemical analysis and a test battery of bioassays covering different modes of action to evaluate the chemical and toxicological profile of source water and treated drinking water in China. The study used iceberg modelling to determine the contribution of detected chemicals to the observed effect, with estrogenic activity well explained by detected chemicals. 
13. Conley JM, Evans N, Mash H, Rosenblum L, Schenck K, Glassmeyer S, Furlong ET, Kolpin DW, Wilson VS: Comparison of in vitro estrogenic activity and estrogen concentrations in source and treated waters from 25 US drinking water treatment plants, Sci. Total Environ. 2017, 579:16101617. *This study found that estrogenic activity was effectively removed by drinking water treatment processes, with estrogenic activity only detected in three treated drinking water samples compared to sixteen source water samples.

14. Van Zij1 MC, Aneck-Hahn NH, Swart P, Hayward S, Genthe B, De Jager C: Estrogenic activity, chemical levels and health risk assessment of municipal distribution point water from Pretoria and Cape Town, South Africa, Chemosphere 2017, 186:305-313.

15. Lv XM, Lu Y, Yang XM, Dong XR, Ma KP, Xiao SH, Wang YZ, Tang F: Mutagenicity of drinking water sampled from the Yangtze River and Hanshui River (Wuhan section) and correlations with water quality parameters, Sci. Rep. 2015, 5:9572.

16. Zeng Q, Zhang SH, Liao J, Miao DY, Wang XY, Yang P, Yun LJ, Liu AL, Lu WQ: Evaluation of genotoxic effects caused by extracts of chlorinated drinking water using a combination of three different bioassays, J. Hazard. Mater. 2015, 296:23-29.

17. Hebert A, Feliers C, Lecarpentier C, Neale PA, Schlichting R, Thibert S, Escher BI: Bioanalytical assessment of adaptive stress responses in drinking water: A predictive tool to differentiate between micropollutants and disinfection by-products, Water Res. 2018, 132:340-349. *This study applied assays indicative of adaptive stress responses to assess DBP formation in three drinking water distribution systems in France. This study was the first to apply the bioanalytical equivalent concentration (BEQ) approach to assess the contribution of DBPs and micropollutants to the observed effect.

18. Neale PA, Antony A, Bartkow ME, Farre MJ, Heitz A, Kristiana I, Tang JYM, Escher BI: Bioanalytical assessment of the formation of disinfection byproducts in a drinking water treatment plant, Environ. Sci. Technol. 2012, 46:10317-10325.

19. Jeong CH, Wagner ED, Siebert VR, Anduri S, Richardson SD, Daiber EJ, McKague AB, Kogevinas M, Villanueva CM, Goslan EH, Luo WT, Isabelle LM, Pankow JF, Grazuleviciene R, Cordier S, Edwards SC, Righi E, Nieuwenhuijsen MJ, Plewa MJ: Occurrence and toxicity of disinfection byproducts in European drinking waters in relation with the HIWATE epidemiology study, Environ. Sci. Technol. 2012, 46:12120-12128.

20. Pellacani C, Cassoni F, Bocchi C, Martino A, Pinto G, Fontana F, Furlini M, Buschini A: Cytoand genotoxic profile of groundwater used as drinking water supply before and after disinfection, J. Water Health 2016, 14:901-913. 
21. Chou HM, Chao HR, Lin C, Chiang PC, Wang GS, Tsou TC: An improved estrogenic activity reporter gene assay (T47D-KBluc) for detecting estrogenic activity in wastewater and drinking water, Toxicol. Environ. Chem. 2016, 98:376-384.

22. Gou YY, Lin S, Que DE, Tayo LL, Lin DY, Chen KC, Chen FA, Chiang PC, Wang GS, Hsu YC, Chuang KP, Chuang CY, Tsou TC, Chao HR: Estrogenic effects in the influents and effluents of the drinking water treatment plants, Environ. Sci. Pollut. Res. 2016, 23:8518-8528.

23. Lv XM, Xiao SH, Zhang G, Jiang P, Tang F: Occurrence and removal of phenolic endocrine disrupting chemicals in the water treatment processes, Sci. Rep. 2016, 6:22860.

24. Xiao SH, Lv XM, Lu Y, Yang XM, Dong XR, Ma KP, Zeng YF, Jin T, Tang F: Occurrence and change of estrogenic activity in the process of drinking water treatment and distribution, Environ. Sci. Pollut. Res. 2016, 23:16977-16986.

25. Xiao SH, Lv XM, Zeng YF, Jin T, Luo L, Zhang BB, Zhang G, Wang YH, Feng L, Zhu Y, Tang F: Mutagenicity and estrogenicity of raw water and drinking water in an industrialized city in the Yangtze River Delta, Chemosphere 2017, 185:647-655.

26. Escher BI, Allinson M, Altenburger R, Bain PA, Balaguer P, Busch W, Crago J, Denslow ND, Dopp E, Hilscherova K, Humpage AR, Kumar A, Grimaldi M, Jayasinghe BS, Jarosova B, Jia A, Makarov S, Maruya KA, Medvedev A, Mehinto AC, Mendez JE, Poulsen A, Prochazka E, Richard J, Schifferli A, Schlenk D, Scholz S, Shiraish F, Snyder S, Su GY, Tang JYM, van der Burg B, van der Linden SC, Werner I, Westerheide SD, Wong CKC, Yang M, Yeung BHY, Zhang XW, Leusch FDL: Benchmarking organic micropollutants in wastewater, recycled water and drinking water with in vitro bioassays, Environ. Sci. Technol. 2014, 48:1940-1956.

27. Valcárcel Y, Valdehíta A, Becerra E, López de Alda M, Gil A, Gorga M, Petrovic M, Barceló D, Navas JM: Determining the presence of chemicals with suspected endocrine activity in drinking water from the Madrid region (Spain) and assessment of their estrogenic, androgenic and thyroidal activities, Chemosphere 2018, 201:388-398.

28. Chevolleau S, Debrauwer L, Stroheker T, Viglino L, Mourahib I, Meireles MH, Grimaldi M, Balaguer P, di Gioia L: A consolidated method for screening the endocrine activity of drinking water, Food Chem. 2016, 213:274-283.

29. Brand W, de Jongh CM, van der Linden SC, Mennes W, Puijker LM, van Leeuwen CJ, van Wezel AP, Schriks M, Heringa MB: Trigger values for investigation of hormonal activity in drinking water and its sources using CALUX bioassays, Environ. Int. 2013, 55:109-118.

30. Daiber EJ, DeMarini DM, Ravuri SA, Liberatore HK, Cuthbertson AA, Thompson-Klemish A, Byer JD, Schmid JE, Afifi MZ, Blatchley ER, Richardson SD: Progressive increase in disinfection byproducts and mutagenicity from source to tap to swimming pool and spa water: Impact of human inputs, Environ. Sci. Technol. 2016, 50:6652-6662. 
31. Warren SH, Claxton LD, Diliberto J, Hughes TJ, Swank A, Kusnierz DH, Marshall V, DeMarini DM: Survey of the mutagenicity of surface water, sediments, and drinking water from the Penobscot Indian Nation, Chemosphere 2015, 120:690-696. 32. Neale PA, Brack W, Ait-Aissa S, Busch W, Hollender J, Krauss M, Maillot-Marechal E, Munz NA, Schlichting R, Schulze T, Vogler B, Escher BI: Solid-phase extraction as sample preparation of water samples for cell-based and other in vitro bioassays, Environ. Sci.: Process. Impacts 2018, 20:493-504.

33. Neale PA, Ait-Aissa S, Brack W, Creusot N, Denison MS, Deutschmann B, Hilscherova K, Hollert H, Krauss M, Novak J, Schulze T, Seiler TB, Serra H, Shao Y, Escher BI: Linking in vitro effects and detected organic micropollutants in surface water using mixture-toxicity modeling, Environ. Sci. Technol. 2015, 49:14614-14624.

34. Plewa MJ, Wagner ED, Richardson SD: TIC-Tox: A preliminary discussion on identifying the forcing agents of DBP-mediated toxicity of disinfected water, J. Environ. Sci. 2017, 58:208-216. *This study introduced the TIC-Tox approach to identify the DBPs driving the observed effect in drinking water. Using previously published data, the authors found that commonly monitored trihalomethanes and haloacetic acids only explained a small fraction of the effect, with haloacetonitriles and haloacetamides likely to be the main forcing agents.

35. Wagner ED, Plewa MJ: CHO cell cytotoxicity and genotoxicity analyses of disinfection byproducts: An updated review, J. Environ. Sci. 2017, 58:64-76.

36. Prochazka E, Escher BI, Plewa MJ, Leusch FDL: In vitro cytotoxicity and adaptive stress responses to selected haloacetic acid and halobenzoquinone water disinfection byproducts, Chem. Res. Toxicol. 2015, 28:2059-2068.

37. Stalter D, O'Malley E, von Gunten U, Escher BI: Fingerprinting the reactive toxicity pathways of 50 drinking water disinfection by-products, Water Res. 2016, 91:19-30.

38. Zhang SH, Miao DY, Tan L, Liu AL, Lu WQ: Comparative cytotoxic and genotoxic potential of 13 drinking water disinfection by-products using a microplate-based cytotoxicity assay and a developed SOS/umu assay, Mutagenesis 2016, 31:35-41.

39. Wendel FM, Ternes TA, Richardson SD, Duirk SE, Pals JA, Wagner ED, Plewa MJ: Comparative toxicity of high-molecular weight iopamidol disinfection byproducts, Environ. Sci. Technol. Lett. 2016, 3:81-84.

40. Hanigan D, Truong L, Simonich M, Tanguay R, Westerhoff P: Zebrafish embryo toxicity of 15 chlorinated, brominated, and iodinated disinfection by-products, J. Environ. Sci. 2017, 58:302-310. 41. Neale PA, Munz NA, Ait-Aissa S, Altenburger R, Brion F, Busch W, Escher BI, Hilscherova K, Kienle C, Novak J, Seiler TB, Shao Y, Stamm C, Hollender J: Integrating chemical analysis and 
bioanalysis to evaluate the contribution of wastewater effluent on the micropollutant burden in small streams, Sci. Total Environ. 2017, 576:785-795.

42. Leusch FDL, Aneck-Hahn NH, Cavanagh JAE, Du Pasquier D, Hamers T, Hebert A, Neale PA, Scheurer M, Simmons SO, Schriks M: Comparison of in vitro and in vivo bioassays to measure thyroid hormone disrupting activity in water extracts, Chemosphere 2018, 191:868-875.

43. Stalter D, Peters LI, O'Malley E, Tang JYM, Revalor M, Farre MJ, Watson K, von Gunten U, Escher BI: Sample enrichment for bioanalytical assessment of disinfected drinking water: Concentrating the polar, the volatiles, and the unknowns, Environ. Sci. Technol. 2016, 50:64956505. *While most sample extraction methods compatible with bioassays only extract non-volatile and semi-volatile compounds, this study used a combination of extraction methods to capture both volatile and non-volatile DBPs from drinking water samples. The effect of the non-volatile and volatile fractions was assessed, with volatile DBPs found to only have a minor contribution to the oxidative stress response.

44. Escher BI, Aït-Aïssa S, Behnisch PA, Brack W, Brion F, Brouwer A, Buchinger S, Crawford SE, Du Pasquier D, Hamers T, Hettwer K, Hilscherová K, Hollert H, Kase R, Kienle C, Tindall AJ, Tuerk J, van der Oost R, Vermeirssen E, Neale PA: Effect-based trigger values for in vitro and in vivo bioassays performed on surface water extracts supporting the environmental quality standards (EQS) of the European Water Framework Directive, Sci. Total Environ. 2018, 628-629:748-765.

45. Escher BI, Neale PA, Leusch FDL: Effect-based trigger values for in vitro bioassays: Reading across from existing water quality guideline values, Water Res. 2015, 81:137-148. *The study developed a novel read across approach to derive effect-based trigger values (EBTs) for drinking water from existing guideline values. The derived EBTs were applied to existing bioassay data for water samples, with the EBTs generally shown to be able to differentiate between drinking water and more chemically contaminated water samples.

46. Escher BI, van Daele C, Dutt M, Tang JYM, Altenburger R: Most oxidative stress response in water samples comes from unknown chemicals: The need for effect-based water quality trigger values, Environ. Sci. Technol. 2013, 47:7002-7011.

47. Escher BI, Dutt M, Maylin E, Tang JYM, Toze S, Wolf CR, Lang M: Water quality assessment using the AREc32 reporter gene assay indicative of the oxidative stress response pathway, J. Environ. Monit. 2012, 14:2877-2885. 
Figure 1: Overview of chemicals potentially present in source water and treated drinking water with the solid arrows indicating the formation of new chemicals after treatment. Comparison of 383 bioanalytical equivalent concentrations before treatment ( $\left.\mathrm{BEQ}_{\text {before tratment }}\right)$ and after treatment 384 (BEQ $\left.\mathrm{Bfter}_{\text {treatment }}\right)$ can shed light on treatment efficiency and disinfection by-product (DBP) 385 formation.

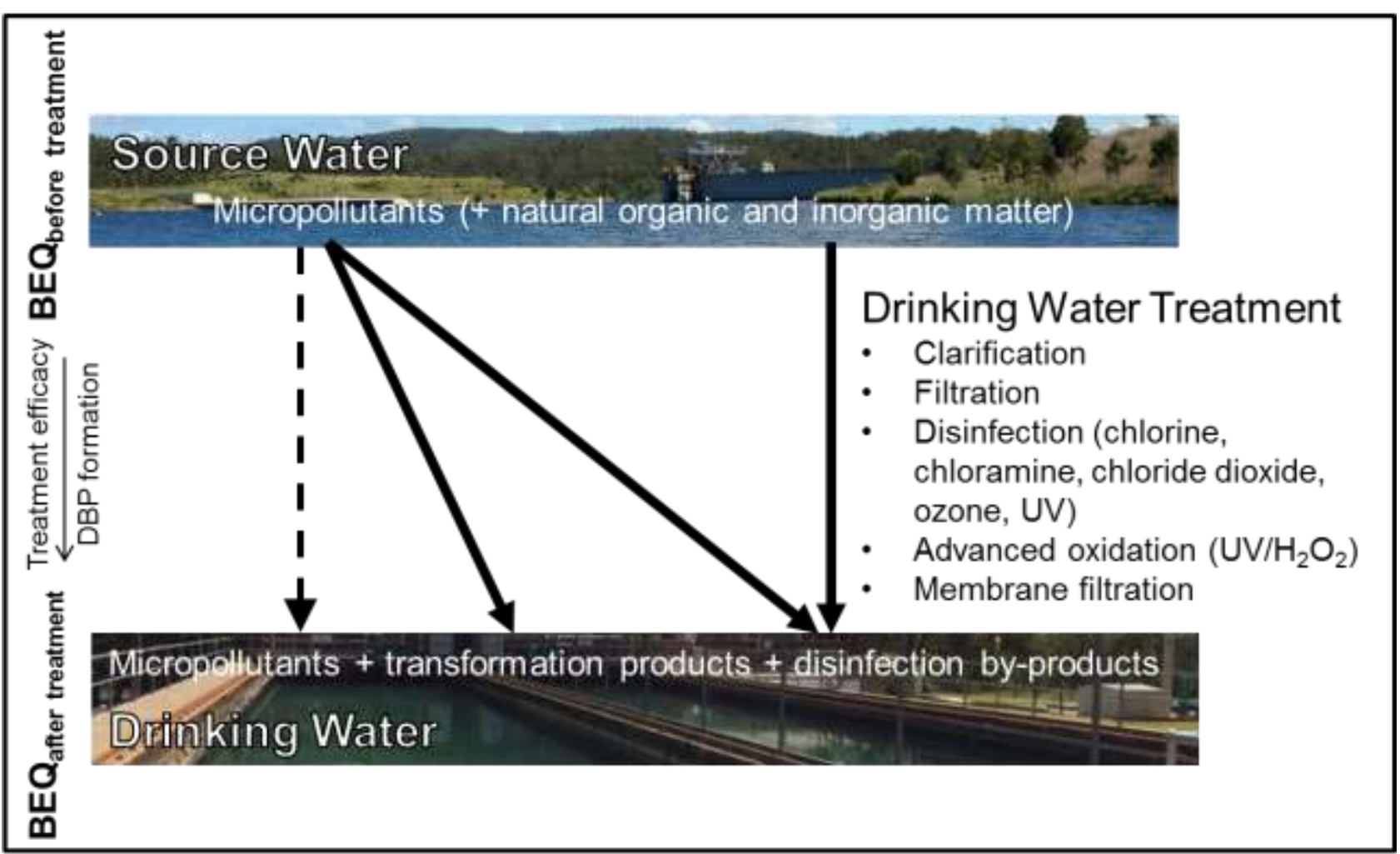


Figure 2: Estradiol equivalent concentrations (EEQ) measured in treated drinking water from around the Netherlands ${ }^{\mathrm{a}}$, China ${ }^{\text {b,d,e, }}$, Taiwan ${ }^{\mathrm{c}, \mathrm{g}}$, United States ${ }^{\mathrm{h}}$, South Africa ${ }^{\mathrm{i}}$ and Sweden ${ }^{\mathrm{j}}$ using 391 different in vitro bioassays for binding to the estrogen receptor. The solid coloured lines indicate 392 effect-based trigger values (EBT) from Escher et al. [45], while the dotted red line indicates the ER 393 CALUX EBT from Brand et al. [29]. No EBT has been developed for the T47D-KBluc or 394 VM7Luc4E2 assays.

395 a Brand et al. [29] (2/3 samples above limit of detection (LOD)), ${ }^{b}$ Shi et al. [12] (2/7 samples above 396 LOD), ${ }^{\mathrm{c}} \mathrm{Gou}$ et al. [22] (maximum EEQ shown only), ${ }^{\mathrm{d}} \mathrm{Lv}$ et al. [23] (4/4 sample above LOD), ${ }^{\mathrm{e} X i a o}$ 397 et al. [24] (22/36 samples above LOD), ${ }^{\mathrm{f} X i a o}$ et al. [25] (8/54 samples above LOD), ${ }^{\mathrm{g}} \mathrm{Chou}$ et al.

398 [21] (average EEQ of 5 samples shown), ${ }^{\mathrm{h}}$ Conley et al. [13] (3/24 samples above LOD), ${ }^{\mathrm{i}}$ Van Zijl et 399 al. [14] (33/80 samples above LOD), ${ }^{j}$ Rosenmai et al. [11] (3/3 samples around LOD)

400

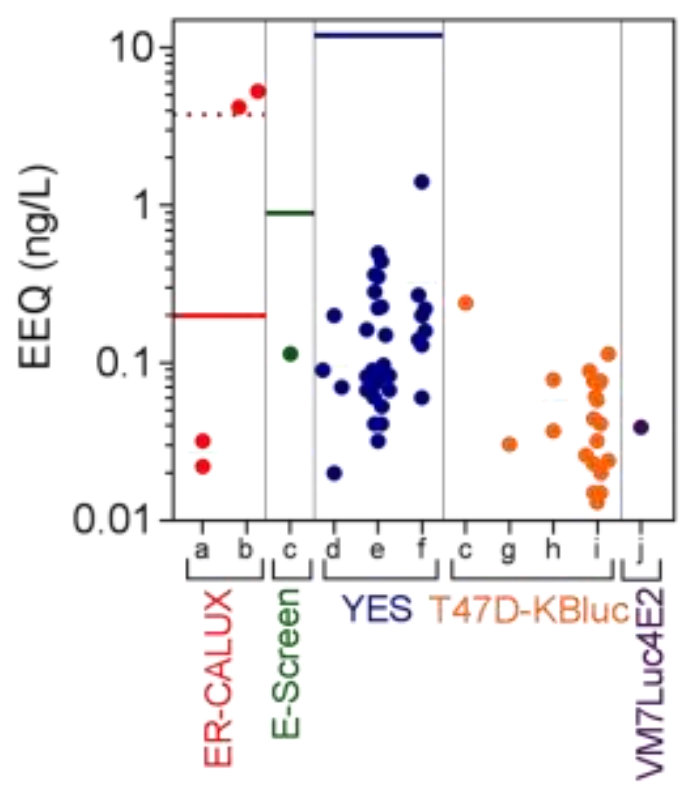

401

402 
403 Figure 3: Application of iceberg modelling to drinking water samples.

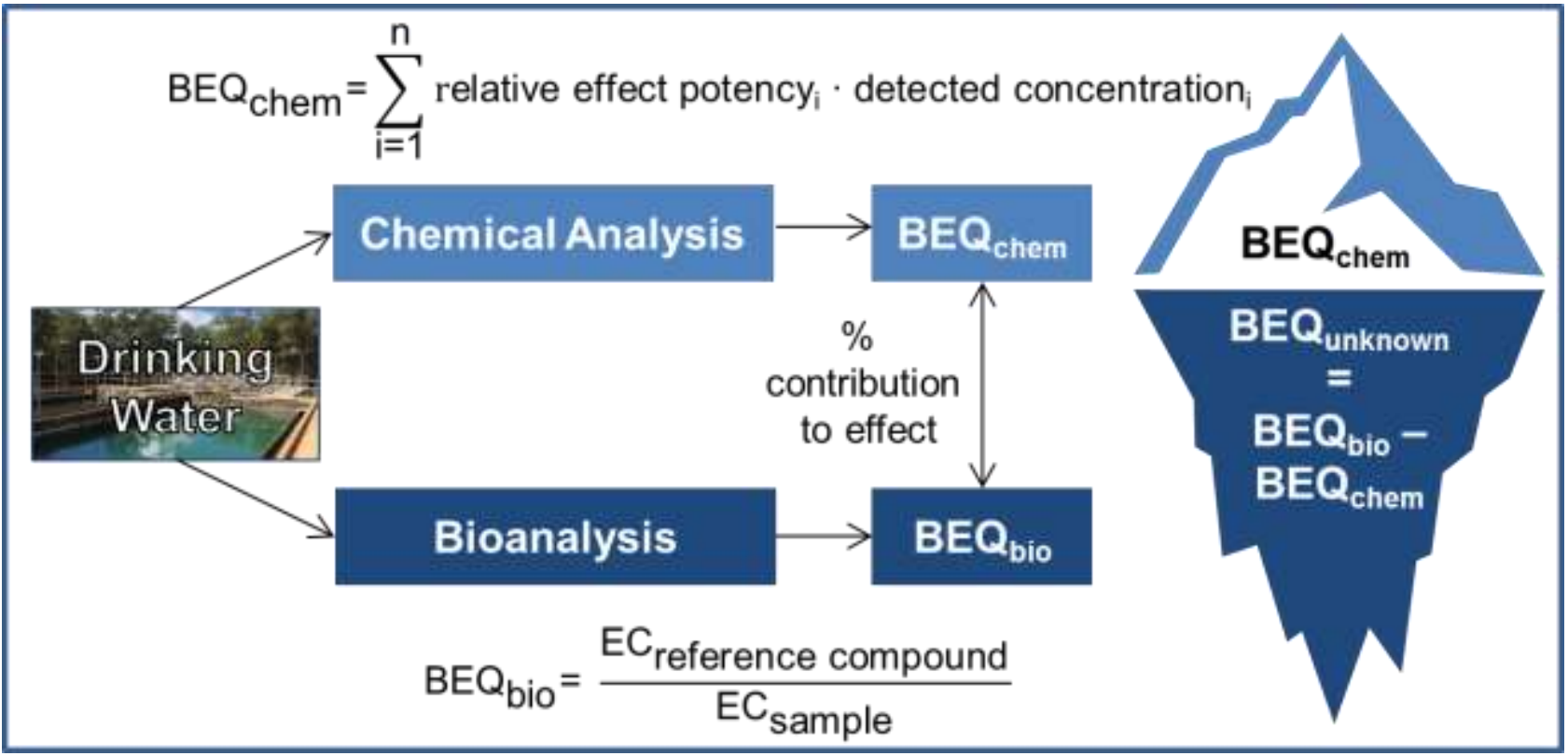

404

405

406 
407 Figure 4: Oxidative stress response, expressed as toxic units (TU), measured in treated drinking 408 water in Australia ${ }^{\mathrm{a}, \mathrm{b}, \mathrm{c}}$ and France ${ }^{\mathrm{d}}$ using the AREc32 and Nrf2-CALUX assays. The solid red line 409 indicates the EBT for the AREc32 assay from Escher et al. [46]. No EBT is available for the Nrf2410 CALUX assay. TU calculated from effect concentration causing an induction ratio of $1.5\left(\mathrm{EC}_{\mathrm{IR} 1.5}\right)$ 411 in units of relative enrichment factor (REF).

412 a Escher et al. [47], ${ }^{\mathrm{b}}$ Neale et al. [18], ${ }^{\mathrm{c}}$ Escher et al. [26], ${ }^{\mathrm{d}}$ Hebert et al. [17]

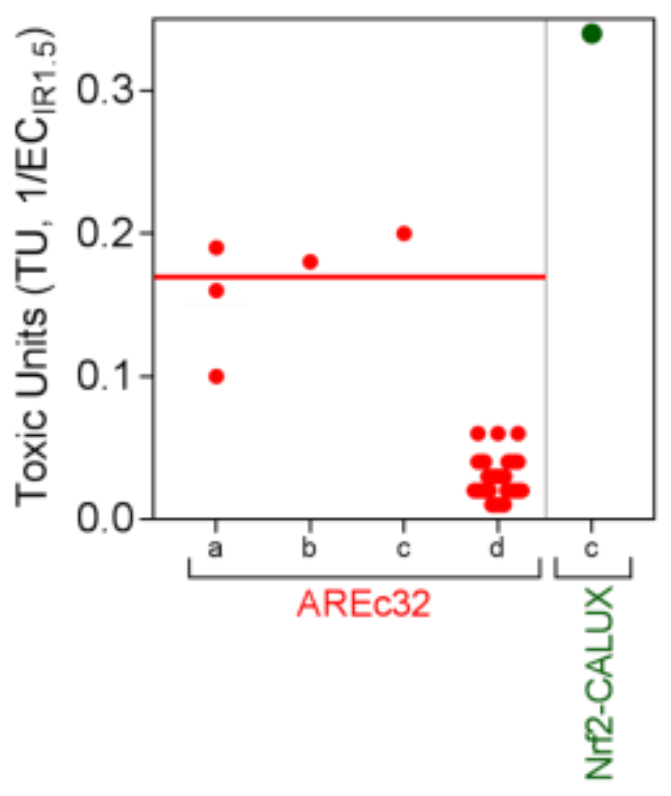

